\title{
The Role of Lomasomes in Wall Formation in Penicillium vermiculatum
}

\author{
By R. WILSENACH ANd M. KESSEL \\ Department of Botany, University of the Witwatersrand, \\ Johannesburg, Republic of South Africa
}

(Received 30 March 1965)

\begin{abstract}
SUMMARY
When ascospores are formed within the ascus each nucleus and associated cytoplasm becomes enclosed by a cell wall. The origin of this wall is traced in a soft cleistothecial species, Penicillium vermiculatum Dangeard. Asci in this fungus arise by budding, and some aspects of bud-wall formation are recorded here.
\end{abstract}

\section{INTRODUCTION}

Very little is known about the formation of the ascospore wall and its subsequent thickening. Moore \& McAlear (1962) reported the origin of the wall as the appearance of a thin electron-transparent shell which subsequently becomes thickened. Moore (1963) gave a more detailed account of ascospore wall thickening, associating the process with the presence of a 'peripheral net' of endoplasmic reticulum against the ascus wall, but gave no account of the initial stages. Because lomasomes have always been observed next to cell walls, we considered the possibility that they might play a role in wall formation. Moore \& McAlear (1961), however, remarked on the absence of lomasomes from ascospores, and in the micrographs of Moore (1963) no lomasomes can be seen. If this be true then the role of the lomasomes in wall formation must be excluded. The present study is a re-investigation of the developmental stages of ascospore walls. New wall development during budding was also followed.

\section{METHOD}

Penicillium vermiculatum Dangeard, isolated from soil near Johannesburg, was grown on sterile cellophan discs on corn meal agar in a Petri dish. Maturing yellow cleistothecia were fixed and prepared for electron microscopy as described elsewhere (Wilsenach \& Kessel, 1965).

\section{RESULTS}

Asci at different stages of development and a number of mature liberated ascospores can be seen with associated nutritive hyphae enclosed by a cleistothecial wall formed by densely packed hyphae in $\mathrm{Pl}$. 1, fig. 1. The existence of all the different stages within a single cleistothecium facilitated the study of developmental changes.

Early bud formation can be seen as an infolding of the wall (Pl. 1, fig. 2). There is evidence that final cytokinesis is not accomplished by this infolding, but a new cell-wall (NBW) is laid down spanning the gap between the infolding walls (IBW) (Pl. 1, fig. 3). A lomasome can be seen on both sides of the newly formed bud wall (P. 1, fig. 4). 
Within the young ascus numerous dark granules (G) which appear to have a compound structure can be seen (Pl. 2, figs. 5, 6). These seem to represent a recently formed metabolic product since their appearance is considerably less in earlier stages (see Pl. 1, fig. 2). The dense appearance of these granules after $\mathrm{KMnO}_{4}$ fixation suggests that they were of lipid nature; and this was confirmed by Sudan IV staining of living mycelium. Their relative abundance decreased sharply during the final stages of ascospore differentiation, during significant increase in ascospore wall thickness (see Pl. 2, figs. 7, 8). It is therefore suggested that this lipid material is incorporated in the ascospore wall.

\section{Ascospore roall formation}

Before wall formation takes place the primary ascus nucleus undergoes three divisions, resulting in 8 nuclei. The first evidence of future wall formation is a sheath consisting of a double membrane which becomes orientated around each nucleus and adjacent cytoplasm (Pl. 2, fig. 6). At earlier stages only strands of endoplasmic reticulum (ER) are present in the cytoplasm (Pl. 2, fig. 5). Before this membrane system (interpreted as endoplasmic reticulum ER) forms a complete sheath, portions of it become swollen (Pl. 3, fig. 9). Very soon after this small vesicles accumulate in the swollen part, which now appears like a lomasome (Pl. 3, fig. 10).

Cell-wall material then begins to accumulate between the two membranes which become pushed apart, the wall at this stage consists of three layers, a thin central electron-dense layer bordered on either side by lighter regions. Lomasomes are now very prominent and they appear between the two membranes, inside the dark wall layer (Pl. 3, fig. 12). In Pl. 3, fig. 11, the relationship between lomasome and endoplasmic reticulum (ER) can clearly be seen. Both the dark layer and the inner lighter region increase in thickness (Pl. 2, fig. 7; Pl. 4, fig. 13). The ectoplast (or plasmalemma) of the ascospore protoplast is therefore derived from the endoplasmic reticulum ER, and so is the spore membrane. Further thickening of the wall is almost entirely limited to the lighter region, but the spines are extensions of the dark layer (Pl. 2, fig. 8; Pl. 4, fig. 14).

\section{DISCUSSION}

Lomasomes were first recorded by Moore \& McAlear (1962) in nine different fungi from all the major groups, and were described as aggregates of vesicles which always appeared against the cell wall. No function was proposed for these organelles, and it was stated that they had not been observed in conidia or ascospores. Since this initial report, lomasomes have been described in other papers on fungal fine structure (Bracker \& Butler, 1963; Gibardt, 1961), but a possible function is not known. These bodies were presumed to be exclusive to the fungi, although Manocha \& Shaw (1964) claimed to have seen similar structures in the mesophyll cells of wheat.

The appearance of the lomasomes between the two membranes of the endoplasmic reticulum (reported for the first time in this paper) immediately precedes the formation of cell-wall material, which is also produced between these same two membranes. The suggestion is therefore made that lomasomes are associated with wall formation. This accounts for the initial appearance of the ascospore wall, which was not explained by Moore \& McAlear (1962) or Moore (1963). The process of cellwall formation described here differs from that described by Moore (1963) who 
reported that a peripheral net of endoplasmic reticulum lies internally to the ectoplast and somehow contributed to the ascospore wall thickening. Moore (1963) could not explain the origin of the spore membrane and suggested that this membrane had a protective function. In the present study the origin of this membrane is explained and is not linked with the function of protection, but is seen as the remains of the endoplasmic reticulum which was involved in cell-wall formation.

Crawley (1965) and Barton (1965) published accounts of a cytoplasmic organelle associated with cell walls in Chara and Nitella, suggesting that its function is involved in wall formation. The structure of these organelles differs from lomasomes in that tubules are present (and not vesicles), and are continuous with the plasmalemma. Although structural differences are present, this organelle has the same topography and the same suggested function as lomasomes. These bodies appear to be homologous with the lomasomes of fungi. In higher plants it has been suggested that the Golgi bodies are involved in cell-plate formation; cell-wall material is said to be contained in the vesicles which subsequently coalesce to form the cell plate (Frey-Wyssling, Lopez-Saez \& Mühlethaler, 1964). It is suggested here that the vesicles of the fungal lomasomes behave in a similar way and it is perhaps significant that Golgi bodies have not been observed in the fungi in which lomasomes have been found.

It is difficult to account for the observation by Moore \& McAlear (1962) that lomasomes were not found in ascospores, unless they had disappeared or become less conspicuous when cell-wall thickening had ceased. Although the initial appearance of the lomasome in the endoplasmic reticulum seems contrary to earlier observations, its final position in the ascospore has the same topography as that described by previous authors, namely between the ectoplast and the cell wall. During active bud-wall formation the lomasome is seen in the typical position (Pl. 1, fig. 4). An interesting confirmation of the role of lomasomes in wall formation was provided by an anomalous chain of buds in which, in a particular ascus, mature ascospores were strangely lobed and multinucleate. In a younger adjacent ascus several nuclei are surrounded by a similarly shaped sheath of endoplasmic reticulum with associated conspicuous lomasomes (Pl. 4, fig. 15).

\section{REFERENCES}

Barton, R. (1965). An unusual organelle in the peripheral cytoplasm of Chara cells. Nature, Lond. 205, 201.

Bracker, C. E. Jun. \& Butler, E. E. (1963). The ultrastructure and development of septa in hyphae of Rhizoctonia solani. Mycologia, 55, 35.

Crawley, J. C. W. (1965). A cytoplasmic organelle associated with the cell walls of Chara and Nitella. Nature, Lond. 205, 200.

GibardT, M. (1961). Licht und elektronen mikroskopische Untersuchungen an Polystictus versicolor. II. Die Feinstruktur von Grundplasma und Mitochondrien. Arch. Mikrobiol. 39, 351.

Frey-Wyssing, A., Lopez-Saez, J. F. \& Mühlethaler, R. (1964). Formation and development of the cell plate. J. Ultrastruct. Res. 10, 422 .

Manocha, M. S. \& Shaw, M. (1964). Occurrence of lomasomes in mesophyll cells of 'Khapli' wheat. Nature, Lond. 203, 1402.

Moore, R. T. (1963). Fine structure of Mycota 1. Electron microscopy of the Discomycete Ascodesmis. Nova Hedreigia, 5, 263.

Moore, R. T. \& McAlear, J. H. (1961). Fine structure of Mycota 5: Lomasomespreviously uncharacterized hyphal structures. Mycologia, 53, 194. 
Moore, R. T. \& MCAlear, J. H. (1962). Observations on ascospore initiation in the Discomycete Dasyscyphus. J. gen. Microbiol. 28, 211.

Wilsenach, R. \& Kessei, M. (1965). On the function and structure of the septal pore of Polyporus rugulosus. J. gen. Microbiol. 40, 397.

\section{EXPLANATION OF PLATES}

Ascospore wall development and the associated role of lomasomes in Penicillium vermiculatum Dangeard. A, ascus; AS, ascopore; ASW, ascospore wall; AW, ascus wall; BW, bud wall; E, ectoplast; EP, epiplasm; ER,endoplasmic reticulum; G, compound lipid granules; IBW, infolding bud wall; Lo, lomasome; Mi, mitochondrion; N, nucleus; NBW, new bud wall; NM, nuclear membrane; $P$, initial ascospore envelope; SM, spore membrane; $W$, wall.

\section{Plate 1}

Fig. 1. Segment through a maturing cleistothecium. The soft cleistothecial wall consists of dark hyphae. Mature and maturing asci can be seen. $\times 3900$.

Fig. 2. Budding of ascogenous hypha. Notice infolding of the bud wall. Relatively few electrondense granules are evident in the cytoplasm. $\times 12,000$.

Fig. 3. Infolding of wall as seen at a later stage, with the new cell wall accomplishing final cytokinesis. $\times 60,000$.

Fig. 4. Lomasome associated with the new bud wall. $\times 60,000$.

\section{Plate 2}

Fig. 5. Dividing nucleus in young ascus. Apparently the nuclear membrane does not disappear during cell division. Endoplasmic reticulum can be seen in the cytoplasm, and the dark granules have increased in abundance. $\times 13,000$.

Fig. 6. Young 8-nucleated ascus. The young ascospore is delimited by endoplasmic reticulum, enclosing cytoplasm and nucleus. The nuclear membrane is not clear at this stage. $\times 12,000$.

Fig. 7. Maturing ascus. The ascospore wall has increased in thickness, the nuclear membrane is clearer and mitochondria can be seen in the ascospore cytoplasm. A large lomasome can be seen associated with the wall of one ascospore. $\times 12,000$.

Fig. 8. Mature ascus. The ascospore wall has become considerably thickened and shows the echinulations characteristic for this species. Notice the disappearance of the dark granules during maturation of the ascus. $\times 12,000$.

\section{Plate 3}

Details of different stages of ascospore wall formation.

Fig. 9. The initial ascospore envelope consists of endoplasmic reticulum (ER) which becomes swollen at places. Approx. $\times 60,000$.

Fig. 10. At a later stage small vesicles appear in the swollen part of the ascospore envelope. This is interpreted as the origin of the lomasomes subsequently seen. $\times 60,000$.

Fig. 11. Conspicuous lomasomes appearing between the two layers of the ER which is the ascospore envelope $(P) . \times 60,000$.

Fig. 12. Wall material is laid down between the two layers of ER. $\times 60,000$.

\section{Plate 4}

Fig. 13. The wall now consists of a thin outer light layer, a thick central dark layer and a thick inner light layer. These three layers can be seen in Fig. 12 and it is clear that the thickening occurs mainly in the dark and inner light layers. The outer membrane of the original ER is now the spore membrane (SM) and the inner layer, the ectoplast. The lomasome now occupies the typical position between the ectoplast and the cell wall. $\times 60,000$.

Fig. 14. Mature ascospore wall showing the considerably thickened light layer. The echinulation appears to arise from the dark layer, and is bounded by the spore membrane (SM). $\times 60,000$.

Fig. 15. Adjacent asci with the one showing a mature lobed ascospore and the other a similar shaped spore in an early stage of development with lomasomes conspicuous in the young ascospore envelope. $\times 12,000$. 

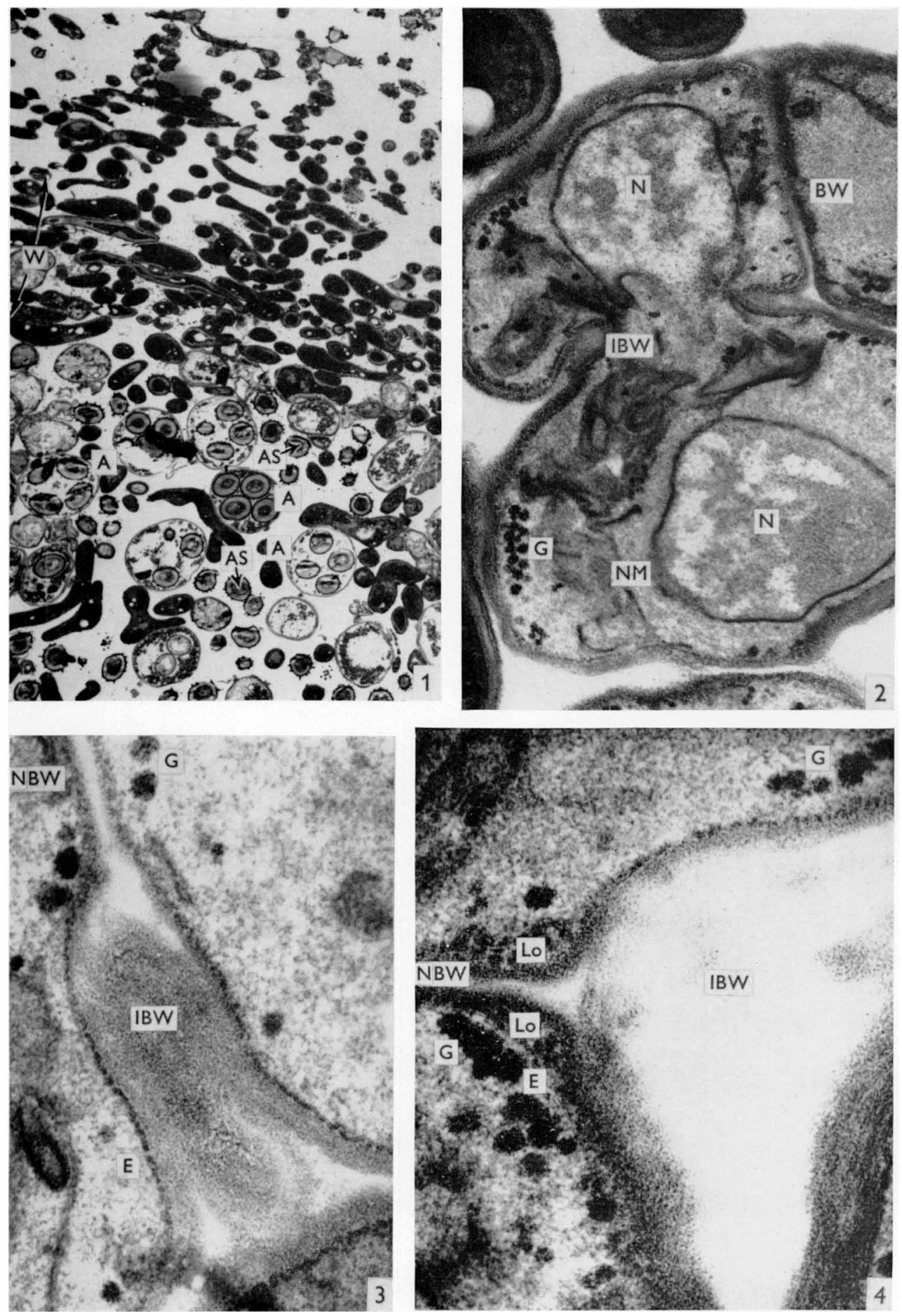

R. WIISFNACH AND M. KESSEI

(Facing p. 404) 

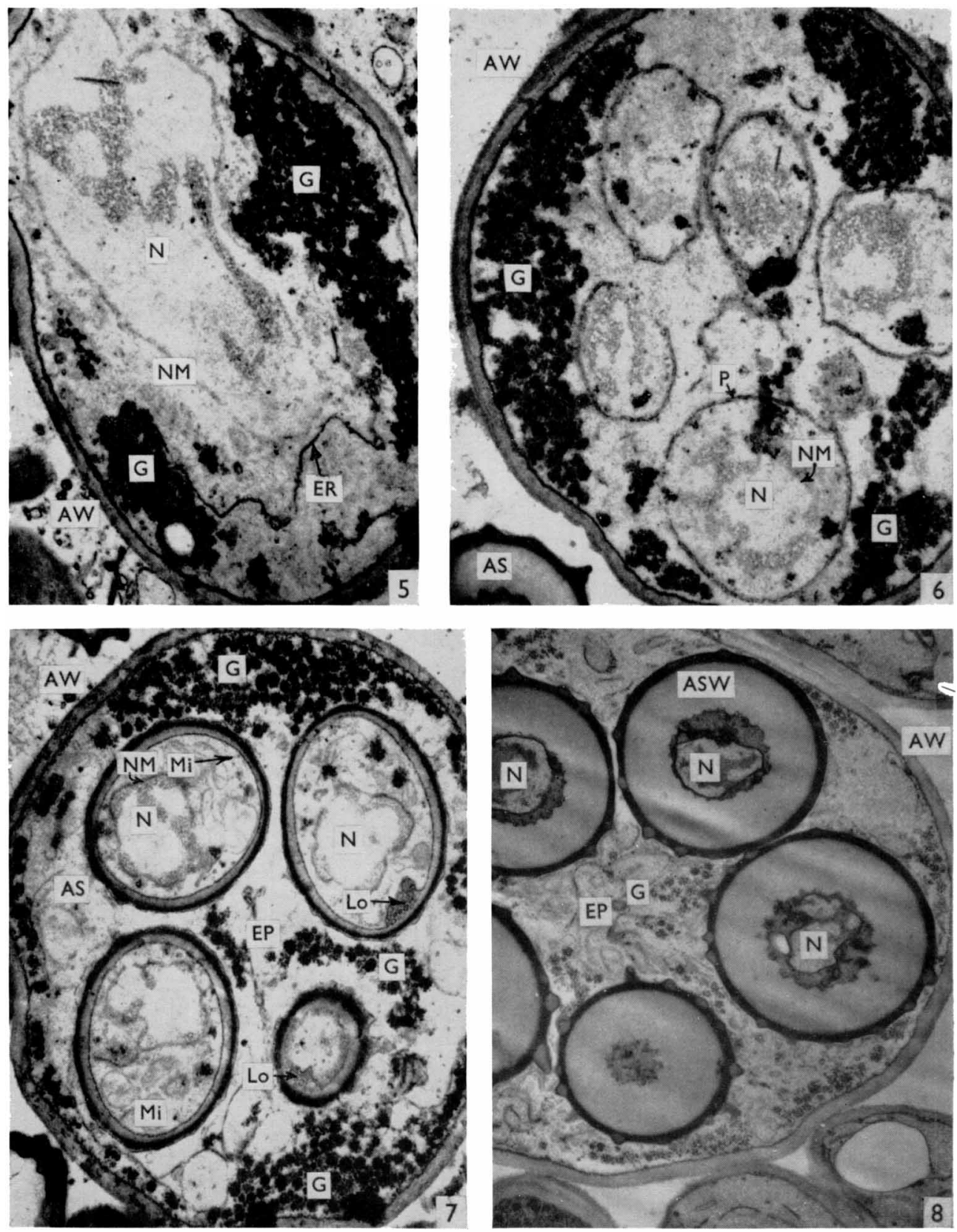

R. WILSENACH AND M. KESSEI. 

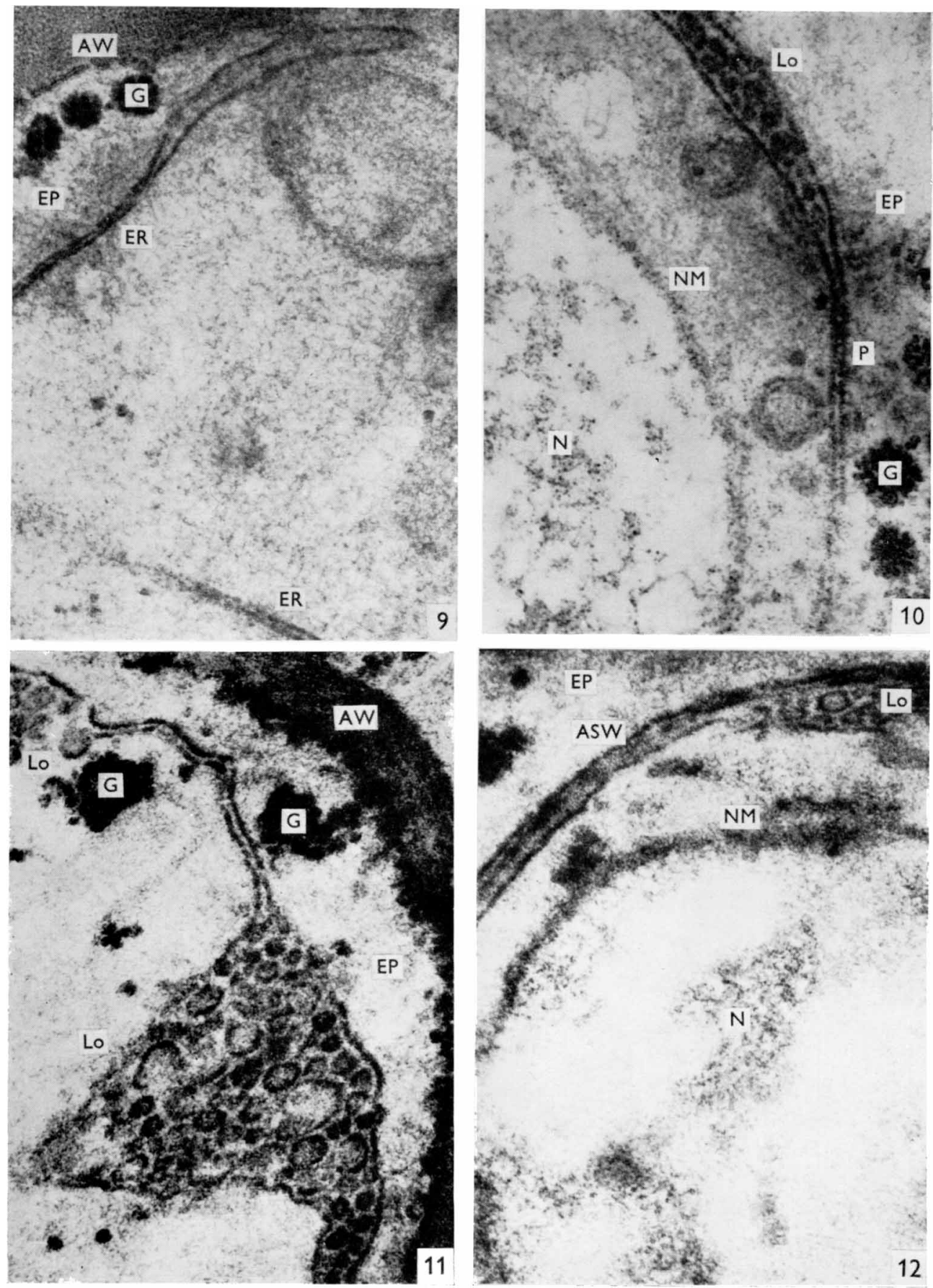

R. WILSENACH AND M. KESSEI, 

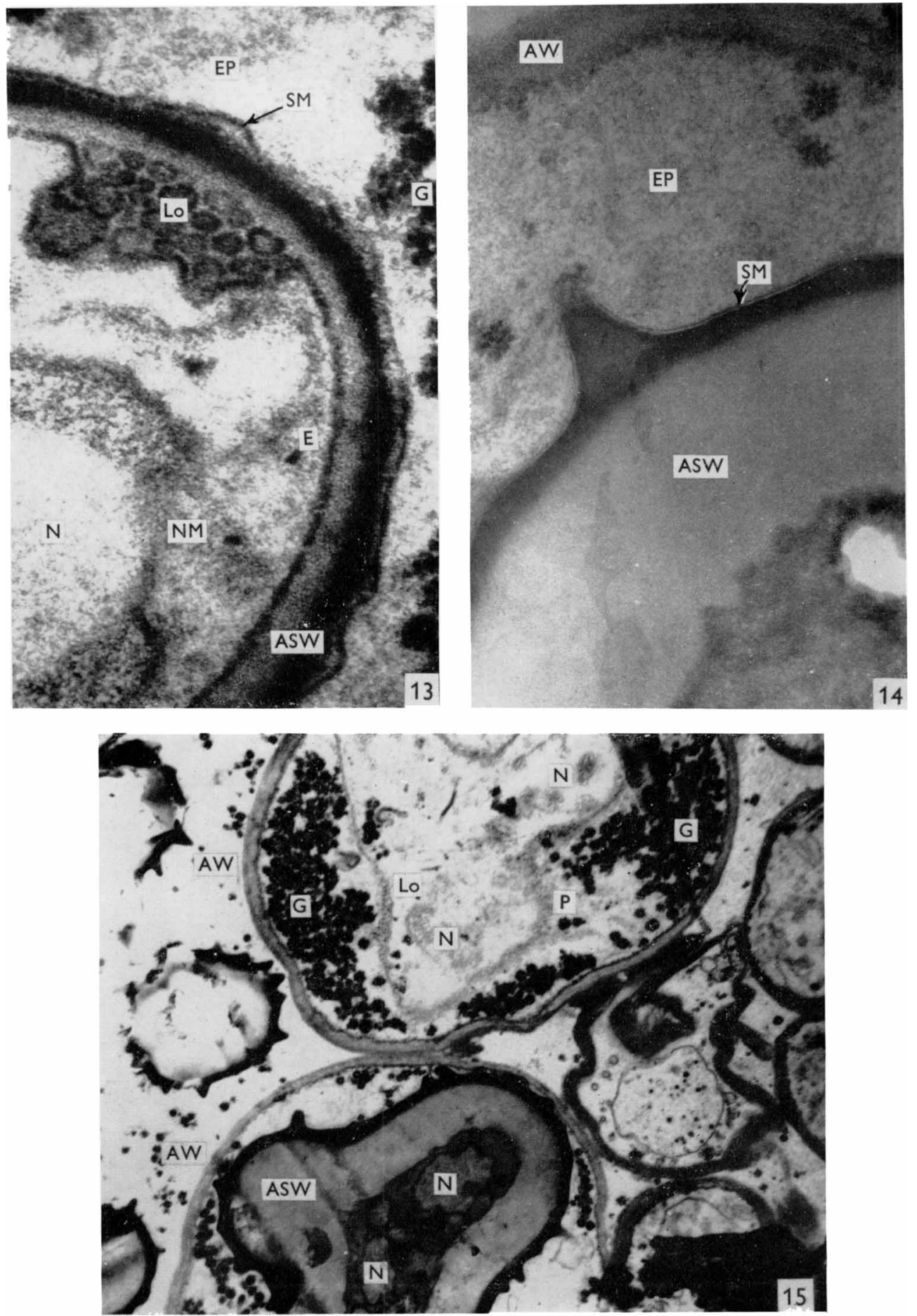

R. WILSENACH AND M. KESSEL. 